\title{
Implementation Analysis for Energy Audit Process at MSRTC Bus Station- A Review Research
}

\author{
Prof. Sunil R. Kewate ${ }^{\# 1}$, Prof. Dr. Vivek R. Gandhewar"2, Kartik D. Ukhalkar ${ }^{* 3}$ \\ ${ }^{1}$ Research Schalor \& Assist. Professor, Mechanical Engg. Dept, Govt. College of Engineering, Amravati, \\ Maharashtra, India, \\ ${ }^{2}$ Associate Professor, Mechanical Engg.Department, Jawaharlal Darda Inst, of Engg.\& Tech. Yavatmal , \\ Maharashtra, India \\ ${ }^{3}$ M.Tech. Student, Mechanical Engg. Dept, Govt. College of Engineering, Amravati, Maharashtra, India
}

\section{Article Info \\ Volume 8, Issue 5 \\ Page Number : $521-526$}

\section{Publication Issue}

September-October-2021

\section{Article History}

Accepted : 16 Oct 2021

Published : 30 Oct 2021

\section{ABSTRACT}

Energy audit consists of survey, analysis and inspection of the energy flow in the system. Its aim is to find the scope of energy conservation by implementing energy saving procedures without affecting the outputs of the system. One such system which can conserve energy is MSRTC bus station which requires a lot of energy consumption for its everyday activities. Energy audit plays a significant role in finding opportunities to save energy and reduce electricity bills. Energy audit recommends ways to save energy consumption by some changes in the system with emphasis on that there are no negative output by the changes made. The Energy Audit would provide a positive orientation to the energy cost reduction along with preventive maintenance and quality control programs which are vital for production and utility activities.

Keywords : Energy Audit, Energy Conservation, Management

\section{INTRODUCTION}

Energy is one of the major factors for the development of any country as it decides the economic growth of the country. The energy consumption in our country is increasing exponentially and to cope up with its requirement puts a tremendous load on the country's resources. The energy generation capacity of India, as of year 2021 is 388,134 MW which is increasing every year but so does the consumption. Almost $60 \%$ of the energy produced is from thermal power plant by consumption of coal. Energy conservation can be the best solution to deal with this situation of increasing energy demand.

As per the Energy Conservation Act 2001, Energy Audit can be defined as 'the verification, monitoring and analysis of use of energy including submission of report containing recommendations for improving the energy efficiency with cost benefit analysis and an action plan to reduce the energy consumption'.

MSRTC bus stand is a very good area for energy conservation. An energy audit of all bus station in the 
state can save a lot of energy as well as lesser electricity bill.

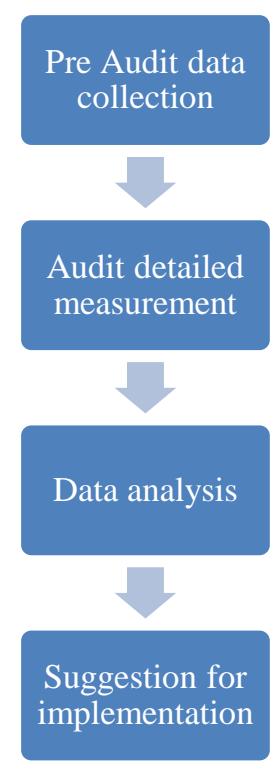

Figure 1: Process of Energy Audit

\section{LITERATURE REVIEW}

This review is based on the various works done in the field of energy audit and management. In reference [2] Manoj et al mentioned their work about energy audit on an academic building with the objective to find possible ways to conserve energy. In their work they found out that highest energy is consumed in lightning loads and personal computers. Replacing all the conventional ballast with electronic ballast and replacing CRT monitor with LCD monitor and using solar water heater instead of geysers were suggested as recommendations to conserve energy. In references $[3,5]$ the energy audit of an educational institute is discussed with ways to conserve energy by replacing all conventional tube lights with LED lights. In paper [4] Sachin et al conducted energy audit of an industry named 'Kohler Power India' Aurangabad. In this paper they have used preliminary energy audit of the plant. Use of LED lamps of equivalent illumination was suggested in place of 250W sodium vapor lamp. In blower, use of VFD-Variable Frequency Drive was also recommended to reduce electric power consumption.

\section{METHODOLOGY}

Preliminary Energy Audit Methodology-It is adopted in case of MSRTC bus station and In order to perform an energy audit, several tasks are typically carried out depending on the type of the audit and function of the building. Based on the requirement some of the tasks may have to be repeated, reduced in scope, or even eliminated. Therefore, the execution of an energy audit is often not a linear process and is rather iterative.

\section{Step 1: Pre-audit data collection}

The main purpose of this step is to evaluate the characteristics of the energy systems and the energy use for the building. The building characteristics can be collected from the architectural or mechanical drawings or from discussions with building operators. The energy use patterns can be obtained from the utility bills over several years. Analysis of the energy consumption from the utility bills allows the energy auditor to determine any seasonal and weather effects on the building energy usage. Some of the tasks that can be performed in this step are presented below, with the key goals expected from each task:

- Identify the fuel types used (to determine the fuel type that accounts for the largest energy use)

- Determine the patterns of fuel use by fuel type (to identify the peak demand for energy use by fuel type)

- Understand utility rate structure (energy and demand rates)

- Analyze the effect of weather on fuel consumption

- Perform utility energy use analysis by building type and size

\section{Step 2: Walk-Through Survey}

In this step we should identify potential for energy savings measures. The results of this step are important since they determine if the building requires any further energy auditing work. Some of the tasks involved in this step are

- Identify the customer's concerns and needs 
- Check the current operating and maintenance procedures

- Determine the existing operating conditions of major energy use equipment

- Estimate the occupancy, equipment, and lighting (energy use density and hours of operation)

\section{Step 3: Baseline for Building Energy Use}

The main purpose of this step is to develop a base model that represents the existing energy use and operating conditions for the building. This will be used as a reference to estimate the energy savings due to appropriately selected energy conservation measures. The major tasks to be performed during this step are

- Inspect, test, and evaluate building equipment for efficiency, performance, and reliability

- Obtain all energy consuming equipment (including lighting and HVAC systems)

\section{Step 4: Evaluation of Energy-Saving Measures}

In this step, a list of cost-effective energy conservation measures is determined using both energy savings and economic analysis. To achieve this goal, the following tasks are recommended:

- Prepare a comprehensive list of energy conservation measures (using the information collected in the walk-through survey)

- Determine the energy savings due to the various energy conservation measures pertinent to the building by using the baseline energy use simulation model developed in Step 3.

- Estimate the initial costs required to implement the energy conservation measures

- Evaluate the cost-effectiveness of each energy conservation measure using an economical analysis method (simple payback or life-cycle cost analysis)

The outcome of this audit can recommend for a detail audit with clear evidence and easily implementable suggestions/solutions can be given to reduce energy consumption.

Preliminary energy audit consists of:
- Scout energy consumption in the organization

- Find the scope for saving

- Identify the most likely areas for attention

- Identify areas of improvements/ savings

- Set a 'reference point'

The data has been collected by visiting the site and note down the observation. Following are the observed data in table 1 and 2 from the site of MSRTC bus stand.

Table I : Details of Lighting Loads

\begin{tabular}{|c|c|c|c|c|c|}
\hline $\begin{array}{l}\text { Details } \\
\text { of the } \\
\text { area }\end{array}$ & $\begin{array}{l}\text { Details } \\
\text { of load } \\
\text { conne } \\
\text { cted }\end{array}$ & $\begin{array}{l}\text { Quan } \\
\text { tity }\end{array}$ & $\begin{array}{l}\text { Watt } \\
\text { age } \\
\text { ratin } \\
\text { g }\end{array}$ & $\begin{array}{l}\text { Operat } \\
\text { ing } \\
\text { load } \\
(\mathrm{kW})\end{array}$ & $\begin{array}{l}\text { Weekl } \\
\text { y } \\
\text { operati } \\
\text { ng } \\
\text { hours }\end{array}$ \\
\hline \multirow{2}{*}{$\begin{array}{l}\text { Main } \\
\text { office, } \\
\text { announc } \\
\text { ement } \\
\text { room, } \\
\text { incharge } \\
\text { room, } \\
\text { passage }\end{array}$} & $\begin{array}{l}\text { LED } \\
30 \mathrm{~W}\end{array}$ & 20 & 30 & 0.6 & 48 \\
\hline & $\begin{array}{l}\text { Plane } \\
\text { FTL } 40 \\
\text { W }\end{array}$ & 4 & 52 & 0.208 & \\
\hline $\begin{array}{l}\text { Passenge } \\
\text { r } \\
\text { Waiting } \\
\text { Hall }\end{array}$ & $\begin{array}{l}\text { LED } \\
30 \mathrm{~W}\end{array}$ & 10 & 30 & 0.3 & 48 \\
\hline Canteen & $\begin{array}{l}\text { LED } \\
30 \mathrm{~W}\end{array}$ & 6 & 30 & 0.18 & 48 \\
\hline $\begin{array}{l}\text { Washro } \\
\text { om }\end{array}$ & $\begin{array}{l}\text { Plane } \\
\text { FTL } 40 \\
\text { W }\end{array}$ & 4 & 52 & 0.208 & 48 \\
\hline
\end{tabular}

Table II : Details of Fan and AC Loads

\begin{tabular}{|l|l|l|l|l|l|}
\hline $\begin{array}{l}\text { Details } \\
\text { of the } \\
\text { area }\end{array}$ & $\begin{array}{l}\text { Details } \\
\text { of load } \\
\text { conne } \\
\text { cted }\end{array}$ & $\begin{array}{l}\text { Quan } \\
\text { tity }\end{array}$ & $\begin{array}{l}\text { Watt } \\
\text { age } \\
\text { ratin } \\
\mathrm{g}\end{array}$ & $\begin{array}{l}\text { Operat } \\
\text { ing } \\
\text { load } \\
(\mathrm{kW})\end{array}$ & $\begin{array}{l}\text { Wee } \\
\mathrm{kly} \\
\text { oper } \\
\text { atin } \\
\mathrm{g} \\
\mathrm{hrs}\end{array}$ \\
\hline Main & Ceilin & 5 & 80 & 0.4 & 48 \\
\hline
\end{tabular}




\begin{tabular}{|c|c|c|c|c|c|}
\hline $\begin{array}{l}\text { office, } \\
\text { announc }\end{array}$ & $\begin{array}{l}\text { g Fan } \\
(48 ”)\end{array}$ & & & & \\
\hline $\begin{array}{l}\text { ement } \\
\text { room, } \\
\text { incharge } \\
\text { room, } \\
\text { passage }\end{array}$ & $\begin{array}{l}\text { Windo } \\
\mathrm{w} \text { A/C } \\
(1.5 \\
\mathrm{TR})\end{array}$ & 2 & 2250 & 4.5 & 48 \\
\hline $\begin{array}{l}\text { Passenge } \\
\text { r } \\
\text { Waiting } \\
\text { Hall }\end{array}$ & $\begin{array}{l}\text { Ceilin } \\
\text { g Fan } \\
\left(48^{\prime \prime}\right)\end{array}$ & 18 & 80 & 1.44 & 48 \\
\hline Canteen & $\begin{array}{l}\text { Ceilin } \\
\text { g Fan } \\
\left(48^{\prime \prime}\right)\end{array}$ & 7 & 80 & 0.56 & 48 \\
\hline $\begin{array}{l}\text { Washro } \\
\text { om }\end{array}$ & $\begin{array}{l}\text { Ceilin } \\
\text { g Fan } \\
\left(48^{\prime \prime}\right)\end{array}$ & 2 & 80 & 0.16 & 48 \\
\hline
\end{tabular}

Table III: Energy Conservation Measures

\begin{tabular}{|c|c|c|c|c|c|c|}
\hline $\begin{array}{l}\text { Particu } \\
\text { lars }\end{array}$ & $\begin{array}{l}\mathrm{Qt} \\
\mathrm{y}\end{array}$ & $\begin{array}{l}\text { Cost } \\
\text { of } \\
\text { devi } \\
\text { ce } \\
\text { per } \\
\text { unit }\end{array}$ & $\begin{array}{l}\text { Saving } \\
\text { of } \\
\text { power } \\
\text { inW/de } \\
\text { vice }\end{array}$ & $\begin{array}{l}\text { Tota } \\
1 \\
\text { cost } \\
\text { of } \\
\text { repl } \\
\text { aced } \\
\text { devi } \\
\text { ce } \\
\text { (in } \\
\text { lac) }\end{array}$ & $\begin{array}{l}\text { Ener } \\
\text { gy } \\
\text { savi } \\
\text { ng } \\
\text { per } \\
\text { year }\end{array}$ & $\begin{array}{l}\text { Mon } \\
\text { etar } \\
\text { y } \\
\text { savi } \\
\text { ng } \\
\text { per } \\
\text { ann } \\
\text { um } \\
\text { (in } \\
\text { lac) }\end{array}$ \\
\hline $\begin{array}{l}\text { Total } \\
\text { numbe } \\
\text { r of } \\
\text { conven } \\
\text { tional } \\
\text { regulat } \\
\text { ors if } \\
\text { replace } \\
d \text { with } \\
\text { electro } \\
\text { nic } \\
\text { regulat } \\
\text { ors }\end{array}$ & 36 & 170 & 8 & $\begin{array}{l}0.06 \\
12\end{array}$ & $\begin{array}{l}718 . \\
84\end{array}$ & $\begin{array}{l}0.04 \\
31\end{array}$ \\
\hline
\end{tabular}

\begin{tabular}{|c|c|c|c|c|c|c|}
\hline $\begin{array}{l}\text { Total } \\
\text { numbe } \\
\text { r of } \\
\text { conven } \\
\text { tional } \\
\text { chokes } \\
\text { if } \\
\text { replace } \\
\text { d with } \\
\text { electro } \\
\text { nic } \\
\text { ballasts }\end{array}$ & 8 & 180 & 11 & $\begin{array}{l}0.14 \\
4\end{array}$ & $\begin{array}{l}219 . \\
64\end{array}$ & $\begin{array}{l}0.00 \\
21\end{array}$ \\
\hline $\begin{array}{l}\text { Total } \\
\text { numbe } \\
\text { r of } \\
\text { tube } \\
\text { rods if } \\
\text { replace } \\
d \text { with } \\
\text { tri } \\
\text { phosph } \\
\text { or rods }\end{array}$ & 8 & 180 & 4 & $\begin{array}{l}0.14 \\
4\end{array}$ & $\begin{array}{l}79.8 \\
7\end{array}$ & $\begin{array}{l}0.00 \\
47\end{array}$ \\
\hline $\begin{array}{l}\text { Total } \\
\text { numbe } \\
r \text { of Air } \\
\text { conditi } \\
\text { oners if } \\
\text { installe } \\
d \text { with } \\
\text { energy } \\
\text { saver }\end{array}$ & 2 & $\begin{array}{l}400 \\
0\end{array}$ & 300 & 0.08 & $\begin{array}{l}1497 \\
.6\end{array}$ & $\begin{array}{l}0.08 \\
9\end{array}$ \\
\hline $\begin{array}{l}\text { Total } \\
\text { no. of } \\
\text { tube } \\
40 \mathrm{WT} \\
\text { with } \\
\text { conven } \\
\text { tional } \\
\text { chokes } \\
\text { if } \\
\text { replace } \\
\text { d }\end{array}$ & 8 & 500 & 23 & 0.04 & $\begin{array}{l}459 . \\
2\end{array}$ & $\begin{array}{l}0.02 \\
7\end{array}$ \\
\hline
\end{tabular}




\begin{tabular}{|l|l|l|l|l|l|l|}
\hline retrofit & & & & & & \\
T-5 & & & & & & \\
rods & & & & & & \\
29WT & & & & & \\
\hline
\end{tabular}

\section{RESULTS AND CONCLUSION}

After analysing the energy consumption in MSRTC bus stand, it has been found out that energy can be saved by:

1. Replacing all conventional chokes by electronic ballast.

2. By replacing total number of tube rods with tri phosphor rods.

3. Total number of conventional regulator if replaced with electronic regulators.

4. Total number of air conditioners if installed with energy saver.

Table IV : The Executive Summary of Energy Audit

\begin{tabular}{|l|l|l|l|}
\hline Measures & $\begin{array}{l}\text { Amt. } \\
\text { saved (in } \\
\text { lac) }\end{array}$ & $\begin{array}{l}\text { Investment } \\
\text { required } \\
\text { (In lac) }\end{array}$ & $\begin{array}{l}\text { Payback } \\
\text { period } \\
\text { (months) }\end{array}$ \\
\hline $\begin{array}{l}\text { Total no. of } \\
\text { conventional } \\
\text { chokes if } \\
\text { replaced by } \\
\text { electronic } \\
\text { ballast }\end{array}$ & 0.021 & 0.016 & 9.14 \\
\hline $\begin{array}{l}\text { Total } \\
\text { number of } \\
\text { tube rods if } \\
\text { replaced } \\
\text { with tri } \\
\text { phosphor } \\
\text { rods }\end{array}$ & 0.0047 & 0.008 & 20.4 \\
\hline $\begin{array}{l}\text { Total } \\
\text { number of } \\
\text { conventional } \\
\text { regulator if } \\
\text { replaced } \\
\text { with }\end{array}$ & 0.0431 & 0.0612 & 17.03 \\
\hline
\end{tabular}

\begin{tabular}{|l|l|l|l|}
\hline $\begin{array}{l}\text { electronic } \\
\text { regulators }\end{array}$ & & & \\
\hline $\begin{array}{l}\text { Total } \text { number of } \\
\text { air }\end{array}$ & 0.089 & 0.08 & 10.7 \\
conditioners & & & \\
if installed & & & \\
with energy & & & \\
saver. & & & \\
\hline $\begin{array}{l}\text { If the total } \\
\text { no. of tube }\end{array}$ & & 0.027 & \\
light fittings & & & \\
are replaced & & & \\
by T-5 & & & \\
fitting & & & \\
\hline
\end{tabular}

Recommendations: Suggestions for saving energy in existing installations and without any investment:

- Unnecessary tube lights to be taken off.

- When lighting not required then it is to be put off timely.

- Regular watch on meter readings.

- Use of Programmable Timers for Switching off the loads on time.

- Proper load should be distributed phase wise and unnecessary meters to be take off.

- Burned meters should be replaced immediately.

- Penalty for power capacitors should be watched.

Looking towards the above aspects the savings achieved by considering above can be up to $8-10 \%$. That will count significant is energy bill.

\section{REFERENCES}

[1]. Anupama Gupta, Pallavi Verma, Richa Priyadarshan "A Review on Energy Management and Audit" International Journal of Advanced Research in Electrical, Electronics and 
Instrumentation Engineering Vol. 4, Issue 2, Cite this article as :

February 2015.

[2]. Manoj Kumar Lamba, Abhishek Sanghi "Energy Audit on Academic Building" International Journal of Engineering Research and General Science Volume 3, Issue 4, JulyAugust, 2015

[3]. Ramya.L.N, M.A.Femina "Energy Auditing - A WalkThrough Survey" International Journal of Advanced Research in Electrical, Electronics and Instrumentation Engineering, Vol. 3, Special Issue 2, April 2014.

[4]. Sachin P. Parthe, Santosh Kompeli "Energy Audit and Conservation Tool for Energy Efficiency" International Research Journal of Engineering and Technology (IRJET) Volume: 02 Issue: 08 | Nov-2015.

[5]. Gousia Sultana, Harsha.H.U "Electrical Energy Audit a Case Study" IOSR Journal of Electrical and Electronics Engineering (IOSR-JEEE) Volume 10, Issue 3 Ver. III (May - Jun. 2015)

[6]. Nikhil M. Dhulekar, Shubham D.Deshmukh, Saurabh P. Dhanawade, Nilesh S. Gajhas "Energy Audit And Energy Saving Management" International Research Journal of Engineering and Technology (IRJET) e-ISSN: 2395-0056 Volume: 07 Issue: 06 | June 2020.

[7]. Awanish kumar, Shashi Ranjan, M.Bharath Kumar Singh, Priyanka Kumari, L.Ramesh "Electrical Energy Audit in Residential House" ScienceDirect Procedia Technology 21 ( 2015 ) $625-630$

[8]. ENERGY MANAGEMENT AND AUDIT HANDBOOK- Bureau of Energy Efficiency

[9]. Ankit Tandon, Jitendra Kasera, Mr.Manish Pokharna "Energy Audit and Management" International Journal of Latest Technology in Engineering Management \& Applied Science (IJLTEMAS)

Prof. Sunil R. Kewate, Prof. Dr. Vivek R. Gandhewar, Kartik D. Ukhalkar, "Implementation Analysis for Energy Audit Process at MSRTC Bus Station- A Review Research", International Journal of Scientific Research in Science and Technology (IJSRST), Online ISSN : 2395-602X, Print ISSN : 2395-6011, Volume 8 Issue 5, pp. 521-526, September-October 2021. Available at

doi : https://doi.org/10.32628/IJSRST218580

Journal URL : https://ijsrst.com/IJSRST218580 